\title{
Pengaruh Budaya Organisasi, Kepuasan Kerja, dan Motivasi Berprestasi Terhadap Komitmen Organisasi Guru SMP Negeri Kecamatan Simanindo dan Kecamatan Pangururan Kabupaten Samosir
}

\author{
Shirley Lusia Marietta Sidabutar, Paningkat Siburian, Salman Bintang \\ Program Studi Administrasi Pendidikan Program Pascasarjana Universitas Negeri Medan \\ UNIMED, Medan, 20221, Sumatera Utara Indonesia \\ Email: shirley.lusiana@gmail.com
}

\begin{abstract}
Abstrak
Penelitian ini bertujuan untuk mendeskripsikan dan mengetahui: (1) Pengaruh Budaya Organisasi Terhadap Kepuasan Kerja; (2) Pengaruh Budaya Organisasi Terhadap Motivasi Berprestasi; (3)Pengaruh Budaya Organisasi Terhadap Komitmen Organisasi; (4) Pengaruh Kepuasan Kerja Terhadap Komitmen Organisasi; dan (5) Pengaruh Motivasi Berprestasi Terhadap Komitmen Organisasi SMP Negeri Kecamatan Simanindo dan Kecamatan Pangururan Kabupaten Samosir. Metode penelitian yang digunakan adalah metode survei yang bersifat exploratori.Jumlah responden sebanyak 158 orang yang diambil dengan sampling random proporsional. Instrumen penelitian berupa angket, sedang analisis data lewat analisis jalur dan sebelumnya ada uji normalitas data dengan liliefors, uji linieritas dan keberartian regresi dengan Analisis Variansi pada taraf signifikansi $\alpha$ sebesar 0,05. Hasil dari penelitian ini ditemukan: (1) terdapat pengaruh langsung positif budaya organisasi terhadap kepuasan kerja dengan koefisien jalur $\rho_{21}=0,210$, dengan pengaruhnya sebesar $4,41 \%$; (2) terdapat pengaruh langsung positif budaya organisasi terhadap motivasi berprestasi dengan koefisien jalur $\rho_{31}=0,381$ dengan pengaruhnya sebesar $14,51 \%$; (3) terdapat pengaruh langsung positif budaya organisasi terhadap komitmen organisasi dengan koefisien jalur $\rho_{41}=0,216$ dengan pengaruhnya sebesar 4,66\%; (4) terdapat pengaruh langsung positif kepuasan kerja terhadap komitmen organisasi dengan koefisien jalur $\rho_{42}=0,269$ dengan pengaruhnya sebesar 7,23\%; (5) terdapat pengaruh langsung positif motivasi berprestasi terhadap komitmen organisasi dengan koefisien jalur $\rho_{43}=0,187$ dengan pengaruhnya sebesar 3,49\%. Semakin tinggi pengaruh budaya organisasi, kepuasan kerja, dan motivasi berprestasi guru, maka semakin tinggi pula dalam mempengaruhi komitmen organisasi guru SMP Negeri kecamatan Simanindo dan kecamatan Pangururan kabupaten Samosir.
\end{abstract}

Kata Kunci: Komitmen Organisasi, Budaya Organisasi, Kepuasan Kerja, Motivasi Berprestasi.

\begin{abstract}
This study aims to describe and know: (1) the influence of organizational culture on job satisfaction; (2) the influence of organizational culture on achievement motivation; (3) the influence of organizational culture to organizational commitment; (4) the influence of job satisfaction to organizational commitment; and (5) the influence of achievement motivation to the organizational commitment of smp negeri simanindo subdistrict and district of pangururan samosir regency. The research method used is survey method that is exploratory. Number of respondents are 158 people were taken with random sampling proportionally. Research instrument in the form of questionnaire, is data analysis through path analysis and previously there is data normality test with liliefors, linearity test and regression significance with Variance Analysis at significance level a equal to 0,05 . The results of this study were found: (1) there was a positive direct effect of
\end{abstract}


organizational culture on job satisfaction with path coefficient $\rho_{21}=0,210$, with influence of 4,41\%; (2) there is a direct positive influence of organizational culture on achievement motivation with path coefficient $\rho 31=0,381$ with influence of $14,51 \%$; (3) there is a positive direct influence of organizational culture on organizational commitment with path coefficient $\rho_{41}=0,216$ with influence 4,66\%; (4) there is a positive direct effect of job satisfaction on organizational commitment with path coefficient $\rho_{42}=0,269$ with its influence equal to 7,23\%; (5) there is a positive direct influence of achievement motivation toward organizational commitment with path coefficient $\rho_{43}=0,187$ with influence 3,49\%. The higher the influence of organizational culture, job satisfaction, and achievement motivation of teachers, the higher also in affecting the commitment of teachers organization SMP Negeri Simanindo district and district Pangururan Samosir district.

Keywords: Organizational Commitment, Organizational Culture, Job Satisfaction, Achievement Motivation.

\section{A. PENDAHULUAN}

Guru sebagai salah satu komponen dalam pendidikan yang memiliki peranan sangat penting dan strategis dalam membimbing peserta didik ke arah kedewasaan, kematangandan kemandirian,sehingga guru sering dikatakan sebagai ujung tombak pendidikan.Guru menjadi faktor kunci keberhasilan dalam pembangunan pendidikan karena guru memiliki kontribusi yang signifikan terhadap pencapaian delapan Standar Nasional Pendidikan yang meliputi: isi, proses, kompetensi lulusan, pendidik dan tenaga kependidikan, sarana dan prasarana, pengelolaan, pembiayaan, dan penilaian. Kualitas guru memiliki pengaruh berantai terhadap komponen pendidikan lainnya, sehingga peningkatan kualitas guru secara nasional merupakan program sangat strategis. Seiring dengan program peningkatan kualitas guru yang dilakukan secara berkelanjutan antara lain melalui sertifikasi guru, uji kompetensi, pelatihan dan penilaian kinerja guru. Kemendikbud kini juga sedang serius mengembangkan model penyiapan guru masa depan sebagaimana amanat undang-undang bahwa Pemerintah mengembangkan sistem pendidikan guru ikatan dinas berasrama di Lembaga Pendidikan Tenaga Kependidikan (LPTK) untuk menjamin efisiensi dan mutu pendidikan (Pasal 23 ayat 1 Undang-Undang Republik Indonesia Nomor 14 Tahun 2005 tentang Guru dan Dosen).

Guru dituntut untuk memiliki komitmen yang tinggi dalam sekolah agar tujuan pembelajaran dan sekolah dapat tercapai. Komitmen yang tinggi dapat mempermudah terwujudnya produktivitas yang lebih tinggi. Guru yang memiliki komitmen kerja yang tinggi akan bekerja secara optimal di sekolah, bertanggung jawab terhadap pekerjaannya, disiplin dalam mematuhi peraturan sekolah, guru akan memberikan pelayanan yang terbaik kepada peserta didik, bangga sebagai profesi guru, menjaga nama baik guru dan tetap setia menjadi seorang guru.

Berdasarkan hasil Uji Kompetensi Guru untuk tahun 2015 diharapkan mencapai nilai minimal 5,5. Namun kenyataannya nilai rata-rata UKG nasional adalah 53,02 dan untuk Sumatera Utara mencapai nilai 48,96.

Rendahnya nilai UKG berdasarkan data di atas khususnya Kabupaten Samosir menunjukkan guru belum memenuhi kualifikasi sebagai guru yang berkompeten khususnya kompetensi pedagogik dan profesional yang berkaitan dengan pengelolaan pembelajaran, untuk itu diperlukan strategi dan upaya dari pemerintah untuk meningkatkan kemampuan Guru dalam menyusun rancangan pembelajaran dengan baik. 
Hal ini masih jauh dari target rencana strategis yang diajukan oleh kementerian pendidikan nasional.

Fenomena lain berdasarkan observasi awal dan hasil wawancara dengan kepala sekolah yang dilakukan pada bulan Januari 2016 pada Sekolah Menengah Pertama (SMP) Negeri di Kecamatan Simanindo, ditemukan masalah pada komitmen kerja guru yang masih kurang baik di sekolah. Adapun fenomena yang menunjukkannya antara lain : (1) guru yang tidak setia terhadap profesinya, hal ini ditunjukkan dari adanya guru yang memiliki pekerjaan lain dan mengutamakan pekerjaan lain tersebut dibandingkan profesinya sebagai guru; (2) guru tidak setia dalam organisasi sekolah, ditunjukkan dengan masih ada guru yang tidak terlibat dalam kegiatan-kegiatan di sekolah seperti rapat guru, pentas seni, KKG dan MGMP; (3) tanggung jawab kerja yang rendah, hal ini ditunjukkan dengan masih ada guru yang meninggalkan kelas sebelum jam pelajaran berakhir dan menunda tugas yang harus dikerjakan; (4) guru belum sepenuhnya memberikan pelayanan yang terbaik kepada peserta didik, ditunjukkan dengan masih ada guru yang belum menyiapkan rencana perangkat pembelajaran dan jarang melakukaninovasi dalam pembelajaran;(5) belum bangga terhadap profesi guru, ditunjukkan dengan masih ada guru yang tidak sungguh-sungguh dalam mengajar dan tidak menjaga perilaku yang benar dihadapan peserta didik. Selain itu, terdapat juga masalah lain yang terjadi di sekolah antara lain: masih ada guru yang terlambat masuk ke kelas dan pulang sebelum waktunya, ketidakpedulian terhadap kegiatan-kegiatan guru dalam mengembangkan dan meningkatkan kualitas guru, masih ada guru yang tidak menggunakan alat peraga dalam proses belajar mengajar, dan terdapat guru yang tidak mau menjalin kerja sama dengan guru lain yang disebabkan oleh permasalahan pribadi. Komitmen organisasi guru berperan penting dalam meningkatkan kualitas pendidikan di sekolah, apabila komitmen organisasi guru di SMP Negeri Kecamatan Simanindo dan Kecamatan Pangururan masih kurang baik maka dapat menghambat proses pembentukan SDM yang berkualitas.

Beranjak dari fenomena masalah komitmen organisasi guru tersebut bila dikaitkan dengan pendapat para ahli, dapat diketahui bahwabanyak faktor yang dapat mempengaruhi komitmen guru. Seperti pendapat yang dikemukakan oleh Qolquitt, et al. (2009:34), faktor yang mempengaruhi komitmen guru yaitu: budaya organisasi, struktur organisasi, kepemimpinan dan pengaruh pemimpin, proses kelompok, karakter kelompok, kemampuan, individu dan nilai-nilai budaya dalam organisasi, kepuasan kerja, kemampuan mengelola stres, motivasi berprestasi, hukuman, pembelajaran dan pengambilan keputusan. Rivai (2009:21) mengatakan faktor-faktor yang mempengaruhi komitmen seorang karyawan yang perlu dipertimbangkan dan diperhatikan adalah ability dan motivation.Dikatakan ability adalah knowledge dan skill, selanjutnya motivation adalah attitude dan situation.Namun dalam penelitian ini yang diduga faktor yang mempengaruhi komitmen organisasi guru adalah budaya organisasi, kepuasan kerja, dan motivasi berprestasi.

Berdasarkan uraian tersebut di atas, maka dapat disintesiskan bahwa melalui budaya organisasi, kepuasan kerja, dan motivasi berprestasi akan mampu menghasilkan komitmen guru yang lebih baik pula. Oleh karena itu, telah dilakukan suatu penelitian yang berjudul "Pengaruh Budaya Organisasi, Kepuasan Kerja, dan Motivasi Berprestasi terhadap Komitmen Organisasi Guru SMP Negeri Kecamatan Simanindo dan Kecamatan Pangururan Kabupaten Samosir.”

\section{B. TINJAUAN PUSTAKA}




\section{Komitmen Organisasi}

Mathis dan Jackson (2000:99) memberi definisi: "Organizational commitment is degrre to which employees believe in and accept organizational goals and desire to remain with the organization". Komitmen organisasi guru merupakan derajat kepercayaannya untuk menerima tujuan-tujuan organisasi/lembaga dan menginginkan untuk tinggal dalam organisasi.Sama halnya dengan pendapat Colquitt, et al. (2009:67) bahwa komitmen organisasi didefinisikan sebagai keinginan seorang karyawan untuk tetap menjadi anggota organisasi.Seseorang guru yang memiliki komitmen organisasi yang tinggi terhadap organisasi sekolah tempatnya bertugas, tidak berkehendak meninggalkan sekolah tersebut, karena merasa bahwa tujuan organisasi sesuai dengan tujuannya.

Menurut Luthans (1992: 249) definisi komitmen organisasi sebagai sikap adalah: (1) keinginan kuat untuk tetap sebagai anggota organisasi; (2) keinginan untuk berusaha keras sesuai keinginan organisasi; dan (3) keyakinan tertentu dan penerimaan nilai dan tujuan organisasi. sekolah. Robbins (1991:164) komitmen organisasi itu sebagai orientasi seorang pegawai terhadap organisasi dalam bentuk kesetiaan melaksanakan tugas, identifikasi terhadap nilai-nilai dan tujuan organisasi, dan keterlibatan kerja untuk berprestasi.Robbins menyatakan bahwa komitmen organisasi dibentuk oleh sikap sebagai akibat dari ketidakcocokan, perasaan suka atau tidak suka pegawai terhadap sesuatu karena adanya persepsi dari beberapa sikapnya.

Steers dan Black dalam Sopiah (2008:157) menyatakan bahwa karyawan yang memiliki komitmen organisasi yang tinggi memiliki ciri-ciri sebagai berikut: (a) adanya kepercayaan dan penerimaan yang kuat terhadap nilai dan tujuan organisasi; (b) adanya kesediaan untuk berusaha sebaik mungkin demi organisasi; (c) keinginan yang kuat untuk menjadi anggota organisasi. Seseorang yang memiliki komitmen akan senantiasa tahu diri, terbuka, toleransi, dan bersikap objektif, mengutamakan kebersamaan, memiliki integritas diri yang kuat, bekerja keras, dan memiliki motivasi yang tinggi untuk menjadi yang terbaik.Steers dan Black dalam Sopiah (2008:157) menyatakan bahwa karyawan yang memiliki komitmen organisasi yang tinggi memiliki ciri-ciri sebagai berikut: (a) adanya kepercayaan dan penerimaan yang kuat terhadap nilai dan tujuan organisasi; (b) adanya kesediaan untuk berusaha sebaik mungkin demi organisasi; (c) keinginan yang kuat untuk menjadi anggota organisasi. Seseorang yang memiliki komitmen akan senantiasa tahu diri, terbuka, toleransi, dan bersikap objektif, mengutamakan kebersamaan, memiliki integritas diri yang kuat, bekerja keras, dan memiliki motivasi yang tinggi untuk menjadi yang terbaik.

Berdasarkan uraian di atas, dapat dikemukakan bahwa komitmen organisasi guru dalam penelitian ini adalah bentuk keterikatan psikologis pada lembaga yang ditandai dengan kepercayaan dan penerimaan nilai-nilai lembaga dan dorongan yang kuat melakukan usaha-usaha dalam mencapai visidan misi serta keinginan yang kuat untuk mempertahankan eksistensinya, dengan indikator: penerimaan nilai-nilai dan tujuan organisasi (komitmen afektif), rasa bangga dan kesediaan bekerja keras untuk lembaga (komitmen berkelanjutan), dan keinginan untuk mempertahankan keanggotaan dalam lembaga (komitmen normatif).

\section{Budaya Organisasi}

Budaya organisasi menurut Qolquitt, et al. (2009:546) adalah pengetahuan sosial bersama dalam suatu organisasi mengenai aturan, norma, dan nilai-nilai yang membentuk sikap dan perilaku karyawan. Definisi ini membantu menyoroti sejumlak aspek dari budaya organisasi.Pertama, budaya adalah pengetahuan sosial diantara anggota 
organisasi. Karyawan belajar tentang aspek yang paling penting dari budaya melalui karyawan lain. Kedua, budaya memberitahu karyawan apa aturan, norma, dan nilai-nilai organisasi. Apa hasil pekerjaan yang paling penting untuk difokuskan. Ketiga, budaya organisasi membentuk dan memperkuat sikap karyawan tertentu dan perilaku dengan menciptakan sistem kontrol atas karyawan.

Robbins dan Judge (2009:551) menyatakan bahwa budaya organisasi mengacu ke suatu sistem makna bersama yang dibentuk oleh anggota-anggotanya sekaligus pembeda organisasi.Berdasarkan pendapat tersebut, dapat dinyatakan bahwa setiap organisasi memiliki budaya organisasi yang merupakan ciri khas, sekaligus merupakan pembeda dengan organisasi lainnya.

Menurut Robbins dan Judge (2009:551) ada tujuh karakteristik primer yang merupakan hakikat dari budaya organisasi antara lain:1) inovasi dan pengambilan resiko, 2) perhatian terhadap detail, 3) orientasi hasil, 4) orientasi orang, 5) orientasi tim, 6) keagresifan, dan 7) kemantapan. Budaya organisasi berhubungan dengan bagaimana karyawanmempersepsikan karakteristik dari budaya suatu organisasi, tidak dengan apakah mereka menyukai budaya itu atau tidak.

Berdasarkan uraian di atas, dapat diduga bahwa budaya organisasi sekolah dalam penelitian ini adalah seperangkat nilai-nilai, norma, asumsi, kepercayaan, prinsip-prinsip, dan kebiasaan atau peraturan yang berlaku di dalam suatu organisasi yang mengatur dan mengarahkan perilaku anggota-anggotanya dalam upaya melakukan suatu pekerjaan dalam memecahkan masalah, dengan indikator: 1) inovasi dan pengambilan resiko, 2) perhatian terhadap detail, 3) orientasi hasil, 4) orientasi orang,5) orientasi tim, 6) keagresifan, dan 7) kemantapan.

\section{Kepuasan Kerja}

Menurut Qolquitt, et al. (2009:105) kepuasan kerja adalah tingkat perasaan menyenangkan yang diperoleh dari penilaian pekerjaan seseorang atau pengalaman kerja. Dengan kata lain kepuasan kerja mencerminkan bagaimana kita merasakan tentang pekerjaan kita dan apa yang kita pikirkan tentang pekerjaan kita. Kepuasan kerja sebagai perasaan positif tentang pekerjaan sebagai hasil evaluasi dari karakteristiknya (Robbins dan Judge, 2009:114).Pekerjaan memerlukan interaksi dengan rekan sekerja dan atasan, mengikuti aturan dan kebijakan organisasional, memenuhi standar kinerja, hidup dengan kondisi kerja kurang ideal dan semacamnya.

Qolquitt, et al. (2009:107) mengemukakan adanya beberapa kategori kepuasan kerja, antara lain: 1) Pay Satisfaction, mencerminkan perasaan pekerja tentang bayaran mereka, termasuk apakah sebanyak yang mereka berhak mendapatkan, diperoleh dengan aman, dan cukup untuk pengeluaran normal dan kemewahan; 2) Promotion Satisfaction, mencerminkan perasaan pekerja tentang kebijakan promosi perusahaan dan pelaksanaannya, termasuk apakah promosi sering diberikan, dilakukan dengan jujur, dan berdasar pada kemampuan; 3) Supervision Satisfaction, mencerminkan perasaan pekerja tentang atasan mereka, termasuk apakah atasan mereka kompeten, sopan dan komunikator yang baik, dan bukannya bersifat pemalas, mengganggu, dan menjaga jarak. Kebanyakan pekerja mengharapkan atasan membantu mereka mendapatkan apa yang mereka hargai. Hal ini tergantung apakah atasan memberikan penghargaan atas kinerja yang baik, membantu pekerja mendapatkan sumber daya yang diperlukan, dan melindungi pekerja dari kebingungan yang tidak perlu; 4) Coworker Satisfaction, mencerminkan perasaan pekerja tentang teman sekerja mereka, termasuk apakah rekan sekerja mereka cerdas, bertanggung jawab, membantu, menyenangkan, dan menarik. Pekerja mengharapkan rekan sekerjanya membantu dalam pekerjaan.Hal ini penting 
karena kebanyakan dalam batas tertentu mengandalkan pada rekan sekerja dalam menjalankan tugas pekerjaan. Di sisi lain, kita mengharapkan senang bekerja bersama mereka, karena menggunakan banyak waktu bersama rekan kerja; 5) Satisfaction with the Work itself, mencerminkan perasaan pekerja tentang tugas pekerjaan mereka sebenarnya, termasuk apabila tugasnya menantang, menarik, dihormati, dan memanfaatkan keterampilan penting daripada sifat pekerjaan yang menjemukan, berulang-ulang dan tidak nyaman; 6) Altruism, merupakan sifat suka membantu orang lain dan menjadi penyebab moral; 7) Status, menyangkut prestise, mempunyai kekuasaan atas orang lain, atau memiliki popularitas; 8) Environment, lingkungan menunjukkan perasaan nyaman dan aman. Lingkungan kerja yang baik dapat menciptakan quality of worklife di tempat pekerjaan.

Berdasarkan beberapa penjelasan di atas merujuk dari teori Colquitt, LePine dan Wesson, dapat disintesiskan bahwa kepuasan kerja merupakan keadaan emosional yang positif dari seseorang yang ditimbulkan dari penghargaan atas sesuatu pekerjaan dengan indikator: 1) kepuasan gaji,2) kepuasan promosi, 3) kepuasan sosial, 4) kepuasan supervisi,5) kepuasan atas pekerjaan, 6) kepuasan status, 7) kepuasan lingkungan kerja, dan 8) kepuasan teman kerja.

\section{Motivasi Berprestasi}

Luthans (1992:147) mengemukakan definisi mengenai motivasi sebagai berikut: "Motivation is a process that starts with a physiological deficiency or need that activates behavior or a drive that is aimed at a goal or incentive". Artinya motivasi yang dimulai dengan proses kekurangan fisiologis atau kebutuhan yang mengaktifkan perilaku dan dorongan yang ditujukan untuk suatu tujuan. Selanjutnya menurut Qolquitt, et al. (2009:178) mengemukakan "Motivation is defined as a set of energetic forces that originates both within and outside an employee, initiates work-related effort, and determinesits direction, intensity, and persistence".Motivasi didefinisikan sebagai seperangkat kekuatan energitik yang berasal di dalam maupun di luar pekerja, dimulai dari usaha yang berkaitan dengan pekerjaan, dan mempertimbangkan arah, intensitas, dan ketekunannya.

Berdasarkan pendapat-pendapat diatas dapat disimpulkan bahwa motivasi merupakan dorongan untuk bertindak terhadap serangkaian proses perilaku manusia dengan mempertimbangkan arah, intensitas, dan ketekunan pada pencapaian tujuan.

McClelland mendefinisikan kebutuhan akan berprestasi (nAch) sebagai keadaan dorongan internal individu yang mereflesikan sampai seberapa besar sukses penting dan bernilai bagi seseorang. Dalam upaya meneliti kebutuhan orang untuk berprestasi ia menyusun Thematic Apperception Test (TAT) yang berisi sejumlah gambar aktivitasaktivitas yang sedang dilaksanakan. Kebutuhan akan berprestasi didefiniskan sebagai kebutuhan untuk mencapai sesuatu yang sulit. Untuk menguasai, memanipulasi atau mengorganisir objek-objek fisik, manusia, atau ide-ide. Karakteristik orang mempunyai kebutuhan prestasi tinggi antara lain: 1) mempunyai keinginan kuat untuk mengambil tanggung jawab pribadi untuk melaksanakan tugas menyelesaikan masalah yang dihadapi. Ia ingin berperan aktif dan menentukan sendiri tidak menyandarkan diri kepada orang lain, menunggu adanya kesempatan atau nasib baik. Ia memilih teman kerja berdasarkan kompetensi bukan berdasarkan pertemanan. Ia mempunyai tanggunga jawab dan rasa percaya diri; 2) cenderung menentukan tujuan sedang jika menghadapi situasi yang sulit. Ia juga mengambil risiko sedang bukan risiko tinggi atau rendah. Orang dengan kebutuhan prestasi tinggi tidak senang dengan tugas rendah dan risiko rendah; 3) mempunyai keinginan besar untuk mendapatkan balikan kinerja.Orang dengan 
kebutuhan prestasi tinggi ingin mengetahui seberapa baik mereka melakukan tugasnya.Mereka menginginkan informasi mengenai prestasinya apakah sukses atau gagal.

Menurut Kreitner dan Kinicki (2008:149) dari teori McClelland bahwa orangorang yang bermotivasi berprestasi mempunyai tiga karakteristik umum yaitu: 1) bekerja pada tugas-tugas yang sulit; 2) situasi dimana kinerja adalah karena hasil kerja mereka bukan faktor lain seperti keberuntungan; dan 3) mereka menginginkan lebih banyak umpan balik atas kesuksesan atau kegagalan daripada prestasi rendah.

Orang yang motif berprestasinya tinggi menurut teori McClelland dalam Usman (2013:293) bercirikan: 1) bertanggung jawab atas segala perbuatannya, mengaitkan diri pada karier atau hidup masa depan, tidak menyalahkan orang lain dalam kegagalannya; 2) berusaha mencari umpan balik atas segala perbuatannya, selalu bersedia mendengarkan pendapat orang lain sebagai masukan dalam memperbaiki dirinya; 3) berani mengambil risiko dengan penuh perhitungan (menantang dan terwujud) melebihi orang lain, lebih unggul, ingin menciptakan yang terbaik; 4) berusaha melakukan sesuatu secara inovatif dan kreatif (sesuatu yang baru, sesuatu yang tiada duanya), banyak gagasan, dan mampu mewujudkan gagasannya dengan baik. Ingin bebas berkarya, kurang menyenangi sistem yang membatasi geraknya ke arah yang lebih positif; 5) merasa dikejar-kejar waktu, pandai mengatur waktunya, yang dapat dikerjakan sekarang jangan ditunda hari esok; 6) bekerja keras dan bangga atas hasil yang telah dicapai.

Berdasarkan pendapat dan penjelasan di atas, dapat disimpulkan bahwa motivasi berprestasi guru adalah dorongan yang kuat dalam diri seorang guru untuk bekerja keras, sekalipun penuh tantangan dan beresiko dalam melaksanakan tugasnya agar berhasil meraih prestasi yang lebih baik dalam mencapai tujuan yang telah ditetapkan sebelumnya, dengan indikator: 1) bertanggung jawab atas segala perbuatannya, 2) berusaha mencari umpan balik atas segala perbuatannya, 3) berani mengambil risiko dengan penuh perhitungan (menantang dan terwujud) melebihi orang lain, 4) berusaha melakukan sesuatu secara inovatif dan kreatif, 5) merasa dikejar-kejar waktu/pandai mengatur waktunya, dan 6) bekerja keras dan bangga atas hasil yang telah dicapai.

\section{METODE}

Pendekatan analisis yang digunakan dalam penelitian ini adalah analisis jalur (path analisis) atau sering disebut dengan pola hubungan sebab akibat.Penelitian ini juga menggunakan kajian korelatif dengan menempatkan variabel.

Subjek penelitian ini adalah 228 orang guru di SMP Negeri Kecamatan Simanindo dan Kecamatan Pangururan Kabupaten Samosir. Peneliti mengambil jumlah sampel dengan menggunakan nomogram Harry King dengan peluang kekeliruan atau taraf signifikansi $\alpha=0,05$ dengan sampel 158 orang. Teknik pengambilan sampel penelitian digunakan dengan cara proportional random sampling. Pengumpulan data dalam penelitian ini menggunakan kuesioner komitmen organisasi, budaya organisasi, kepuasan kerja, dan motivasi berprestasi yang berbentuk skala Likert.

\section{HASIL PENELITIAN DAN PEMBAHASAN}

\section{Hasil}

Paparan deskriptif hasil penelitian untuk variabel budaya organisasi, kepuasan kerja, motivasi berprestasi, dan komitmen organisasi disajikan pada Tabel 1. 
Tabel 1. Paparan Deskriptif Variabel Penelitian

\begin{tabular}{lllll}
\hline & $\begin{array}{l}\text { Budaya } \\
\text { Organisasi }\end{array}$ & $\begin{array}{l}\text { kepuasan } \\
\text { kerja }\end{array}$ & $\begin{array}{l}\text { motivasi } \\
\text { berprestasi }\end{array}$ & $\begin{array}{l}\text { komitmen } \\
\text { organisasi }\end{array}$ \\
\hline Sampel (n) & 158 & 158 & 158 & 158 \\
Skor min & 65 & 55 & 57 & 59 \\
Skor maks & 115 & 113 & 110 & 104 \\
Mean skor total & 87,49 & 90,45 & 87,69 & 86,45 \\
Standar deviasi & 11,13 & 12,56 & 13,44 & 10,44 \\
Modus & 89,88 & 88,83 & 81,44 & 84,71 \\
Median & 88,86 & 89,32 & 92,73 & 87,17 \\
\hline
\end{tabular}

Tabel 2.Rangkuman Hasil Analisis Korelasi dan Analisi Jalur antara Variabel Eksogenus dengan Variabel Endogenus

\begin{tabular}{ccclcl}
\hline Nomor & $\begin{array}{l}\text { Koefisien } \\
\text { Korelasi }\end{array}$ & Signifikansi & $\begin{array}{l}\text { Koefisien } \\
\text { Jalur }\end{array}$ & $\mathrm{t}_{\text {hitungsignifikansi keterangan }}$ \\
\hline 1 & $\mathrm{r}_{12}=0,210$ & 0,000 & $\rho_{21}=0,210$ & 2,683 & 0,000 Jalur berarti \\
2 & $\mathrm{r}_{13}=0,381$ & 0,000 & $\rho_{31}=0,381$ & 5,147 & $0,000 \quad$ Jalurberarti \\
3 & $\mathrm{r}_{14}=0,343$ & 0,000 & $\rho_{41}=0,216$ & 4,561 & 0,000 Jalur berarti \\
4 & $\mathrm{r}_{24}=0,377$ & 0,000 & $\rho_{42}=0,269$ & 5,084 & 0,000 Jalur berarti \\
5 & $\mathrm{r}_{34=0,359}$ & 0,000 & $\rho_{43}=0,187$ & 4,804 & $0,000 \quad$ Jalur berarti \\
\hline
\end{tabular}

Sesuai persyaratan analisis yang digunakan untuk menguji hipotesis, maka dengan bantuan komputer SPSS for windows versi 21 dilakukan uji normalitas data, uji linieritas dan uji keberartian regresi. Berdasarkan hasil uji normalitas data untuk setiap variabel penelitian didapatkan nilai Asymp. Sig (2-tail-ed)> 0,05, sehingga dapat disimpulkan bahwa data Budaya Organisasi $\left(\mathrm{X}_{1}\right)$, Kepuasan Kerja $\left(\mathrm{X}_{2}\right)$, Motivasi Berprestasi $\left(\mathrm{X}_{3}\right)$, dan Komitmen Organisasi $\left(\mathrm{X}_{4}\right)$ adalah berdistribusi normal. Berdasarkan hasil uji linieritas untuk setiap variabel endogenus atas skor variabel eksogenus didapatkan nilai signifikansi $>0,05$, sehingga dapat disimpulkan bahwa semua bentuk regresi linier. Berdasarkan hasil uji keberartian untuk setiap variabel endogenus atas skor variabel eksogenus didapatkan nilai signifikansi $<0,05$, sehingga dapat disimpulkan bahwa semua koefisien arah regresi berarti. Selanjutnya, dengan bantuan computer SPSS for Windowsversi 21 dilakukan uji korelasi dan uji hipotesis sehingga didapatkan koefisien korelasi dan koefisien jalur antara variabel eksogenus dengan variabel endogenus sebagaimana disajikan pada Table 2.

Berdasakan hasil analisis jalur dapat diketahui bahwa semua koefisien jalur antara variabel eksogenus dengan variabel endogenus adalah signifikan, sehingga dapat disimpulkan bahwa semua hipotesis penelitian yang diajukan diterima, seperti berikut.(1) Budaya Organisasi berpengaruh langsung positif terhadap Kepuasan Kerja Guru SMP.(2) Budaya Organisasi berpengaruh langsung positif terhadap Motivasi Berprestasi Guru SMP.(3) Budaya Organisasi berpengaruh langsung positif terhadap Komitmen Organisasi Guru SMP.(4) Kepuasan Kerja berpengaruh langsung positif terhadap Komitmen Organisasi Guru SMP.(5) Motivasi Berprestasi berpengaruh langsung positif terhadap Komitmen Organisasi Guru SMP.

Berdasarkan hasil perhitungan koefisien jalur yang diperoleh, maka diagram jalur pada paradigma penelitian dapat digambarkan sebagai berikut: 


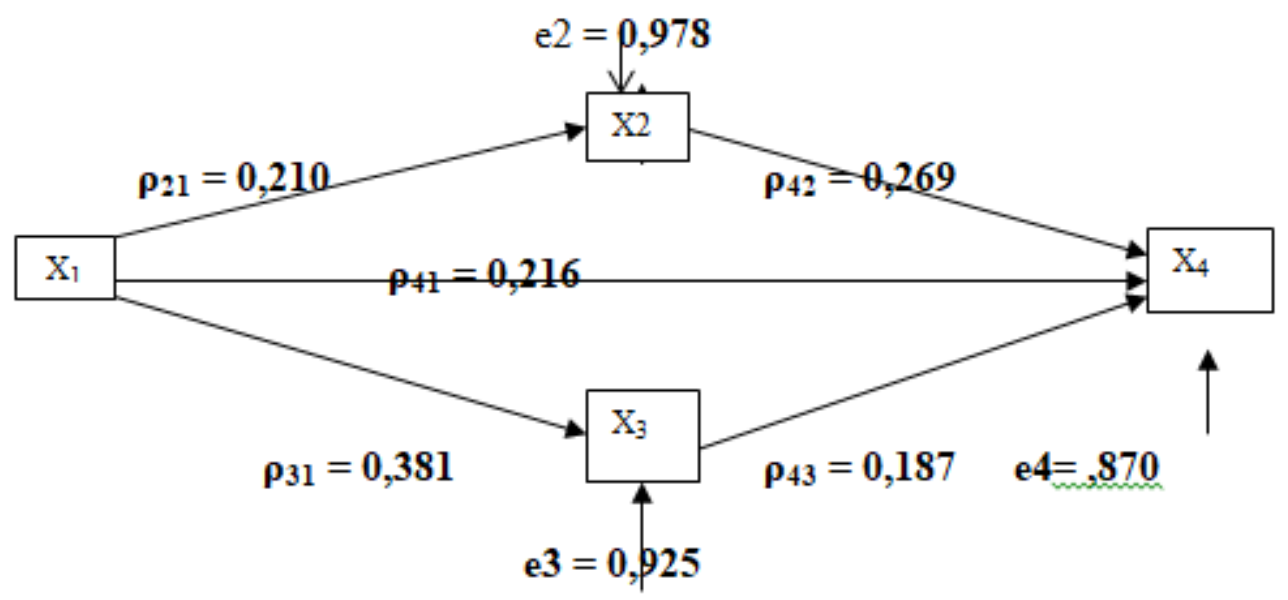

Gambar 1. Diagram Jalur Variabel Penelitian Hasil Pengujian Hipotesis

Keterangan Gambar 4.5:

$\mathrm{X}_{1}=$ Budaya Organisasi

$\mathrm{X}_{2}=$ Kepuasan kerja

$\mathrm{X}_{3}=$ Motivasi Berprestasi

$\mathrm{X}_{4}=$ Komitmen Organisasi

\section{Pembahasan}

Hasil pengujian pertama menunjukkan bahwa terdapat pengaruh langsung positif antara budaya organisasi terhadap kepuasan kerja, yang mana $4,41 \%$ perubahan kepuasan kerja secara langsung dapat ditentukan oleh budaya organisasi.Temuan penelitian ini sesuai dengan hasil penelitian Hutabarat (2014:227) yang menemukan bahwa 17,40\% variasikepuasan kerja dapat dijelaskan budaya organisasidan hasil penelitian Ambarita (2010:212) yang menemukan bahwa budaya organisasisecara langsung berpengaruhpositif signifikanterhadap kepuasan kerja.

Hasil pengujian kedua menunjukkan bahwa terdapat pengaruh langsung positif antara budaya organisasi terhadap motivasi berprestasi, yang mana $14,51 \%$ perubahan motivasi berprestasi secara langsung dapat ditentukan oleh budaya organisasi. Temuan penelitian ini sesuai dengan hasil penelitian Siburian (2015:125) yang menemukan bahwabudaya organisasi secara langsung berpengaruh positif signifikan terhadap motivasi berprestasi sebesar $14,75 \%$. Temuan penelitian ini mendukung teori yang digunakan sebagai dasar pengajuan hipotesis penelitian, yaitu Model Integrasi Perilaku Organisasi dari Colquitt et al. (2009: 102). Kesesuaian temuan penelitian ini dengan hasil penelitian Siburian, teori yang digunakan sebagai dasar pengajuan hipotesis penelitian menunjukkan bahwa teori tersebut masih akurat digunakan menjawab permasalahan yang relevan.

Hasil pengujian ketiga menunjukkan bahwa terdapat pengaruh budaya organisasi secara langsung berpengaruh terhadap komitmen organisasi sebesar 4,66\% perubahan komitmen organisasi secara langsungdapat ditentukan oleh budaya organisasi. Temuanpenelitian ini sesuai dengan hasil penelitian Siregar (2014:100) yang menemukanbahwa budaya organisasi berpengaruhlangsung positif signifikan terhadap komitmen organisasi sebesar 5\%.Temuan penelitian ini mendukung teori yangdigunakan sebagai dasar pengajuan hipotesis penelitian, yaitu: Model Hubungan Budaya Organisasi dengan Komitmen Organisasi dari Robbins dan Judge (2009:608) yang menjelaskan bahwa budaya organisasi secara langsung mempengaruhi komitmen organisasi. Kesesuaian temuan penelitian ini dengan hasil penelitian Siregar, teori yang digunakan 
sebagai dasar pengajuan hipotesispenelitian menunjukkan bahwa teori tersebutmasih akurat digunakan menjawab permasalahanyang relevan.

Hasil pengujian keempat menunjukkan bahwa besarnya pengaruh Kepuasan kerjasecara langsung berpengaruh terhadap Komitmen organisasi guru sebesar 7,23\% perubahan komitmen organisasi secara langsung dapat ditentukan oleh kepuasan kerja. Temuan penelitian ini sesuai dengan hasil penelitian Asiah (2016:122) yang menemukan bahwa kepuasan kerja secara langsung berpengaruh positif signifikan terhadap komitmen organisasi, Temuan penelitian ini mendukung teori yang digunakan sebagai dasar pengajuan hipotesis penelitian, yaitu: Model Integrasi Perilaku Organisasi dari Colquitt et al. (2009:34) yang menjelaskan bahwa kepuasan kerja secara langsung mempengaruhi komitmen organisasi. Jadi, kesesuaian temuan penelitian ini dengan hasil penelitian Asiah dan teori yang digunakan sebagai dasar pengajuan hipotesis penelitian menunjukkan bahwa teori tersebut masih akurat digunakan menjawab permasalahan yang relevan.

Hasil pengujian kelima menunjukkan bahwa besarnya pengaruhmotivasi berprestasi berpengaruh langsungpositif terhadap komitmen organisasi, yang mana 3,49\% perubahan komitmen organisasi secara langsung dapat ditentukanoleh motivasi berprestasi. Temuan penelitianini sesuai dengan hasil penelitian Dasmiati (2013: 115) yang menemukan bahwamotivasi berprestasi secara langsung berpengaruhpositif signifikan terhadap komitmen organisasi. Temuanpenelitian ini mendukung teori yang digunakansebagai dasar pengajuan hipotesis penelitian,yaitu: Model IntegrasiPerilaku Organisasi dari Colquitt, et al. (2009:34) yang menjelaskan bahwa motivasi berprestasisecara langsung mempengaruhi komitmen organisasi. Kesesuaian temuan penelitian ini dengan hasil penelitian Dasmiati dan teori yang digunakan sebagai dasar pengajuan hipotesis penelitian menunjukkanbahwa teori tersebut masih akurat digunakanmenjawab permasalahan yang relevan.

\section{E. KESIMPULAN DAN SARAN}

\section{Kesimpulan}

2. Terdapat pengaruh langsung positif antara budaya organisasi $\left(\mathrm{X}_{1}\right)$ terhadap kepuasan kerja $\left(\mathrm{X}_{2}\right)$. Hal ini menunjukkan bahwa peningkatan budaya organisasi sekolah mengakibatkan terjadinya peningkatan kepuasan kerja guru SMP Negeri Kecamatan Simanindo dan Kecamatan Pangururan Kabupaten Samosir.

3. Terdapat pengaruh langsung positif antara budaya organisasi $\left(\mathrm{X}_{1}\right)$ terhadap motivasi berprestasi $\left(\mathrm{X}_{3}\right)$. Hal ini menunjukkan bahwa peningkatan budaya organisasi mengakibatkan terjadinya peningkatan motivasi berprestasi guru SMP Negeri Kecamatan Simanindo dan Kecamatan Pangururan Kabupaten Samosir.

4. Terdapat pengaruh langsung positif antara budaya organisasi $\left(X_{1}\right)$ terhadap komitmen organisasi $\left(\mathrm{X}_{4}\right)$. Hal ini menunjukkan bahwa peningkatan budaya organisasi mengakibatkan terjadinya peningkatan komitmen organisasi guru SMP Negeri Kecamatan Simanindo dan Kecamatan Pangururan Kabupaten Samosir.

5. Terdapat pengaruh langsung positif antara kepuasan kerja $\left(\mathrm{X}_{2}\right)$ terhadap komitmen organisasi $\left(\mathrm{X}_{4}\right)$. Hal ini menunjukkan bahwa peningkatan kepuasan kerja mengakibatkan terjadinya peningkatan komitmen organisasi guru SMP Negeri Kecamatan Simanindo dan Kecamatan Pangururan Kabupaten Samosir.

6. Terdapat pengaruh langsung positif antara motivasi berprestasi $\left(\mathrm{X}_{3}\right)$ terhadap komitmen organisasi $\left(\mathrm{X}_{4}\right)$. Hal ini menunjukkan bahwa peningkatan motivasi 
berprestasi mengakibatkan terjadinya peningkatan komitmen organisasi guru SMP Negeri Kecamatan Simanindo dan Kecamatan Pangururan Kabupaten Samosir.

\section{Saran}

1. Kepala sekolah hendaknya:

a) Menjaga suasana sekolah yang baik dan kondusif dengan menciptakan kekompakan antara sesama guru, antara guru dan kepala sekolah, antara guru dan warga sekolah serta mampu menciptakan rasa memiliki terhadap sekolah, serta dengan pemberian tugas yang jelas, hubungan imbalan dan hukum yang pasti, keikutsertaan dalam pengambilan keputusan, tekanan pada prestasi, tekanan pada pelatihan dan pengembangan, keamanan dalam melaksanakan tugas, keterbukaan pengakuan dan umpan balik, semangat guru dalam mengajar, dan keluwesan organisasi

b) Melibatkan guru dalam mencari solusi bagi permasalahan yang sedang dihadapi oleh sekolah serta memberikan kesempatan yang merata bagi guru untuk mengembangkan diri.

2. Guru hendaknya:

a) Membangun kerja sama, komunikasi yang terbuka, dan hubungan yang harmonis bagi sesama guru, sehingga apabila salah seorang guru menghadapi kesulitan dapat didiskusikan dan diselesaikan secara bersama dan selalu berpikir positif terhadap kritik dan saran yang diberikan kepala sekolah dan rekan guru lainnya.

b) Guru harus meningkatkan pengetahuan dan pemahaman tentang motivasi berprestasi yang pada hakikatnya adalah kondisi internal seorang guru yang mendorongnya untuk mencapai sebuah prestasi atau keberhasilan dengan selalu aktif mengembangkan diri, menambah wawasan dan pengetahuan untuk mendukung pekerjaannya dalam pembelajaran, saling membagi pengalaman dan informasi baru mengenai hal-hal yang mendukung kegiatan PBM dan membangun empati dan solidaritas dengan sesama.

3. Dinas pendidikan hendaknya:

a) Mendukung dan memberi kesempatan yang merata bagi guru untuk mengembangkan diri seperti memberi kesempatan bagi guru untuk melanjutkan pendidikan ke jenjang yang lebih tinggi.

b) Rutin melakukan kegiatan yang bertujuan untuk meningkatkan kemampuan guru

c) Memberikan reward kepada guru yang berprestasi, sebagai motivasi bagi guru yang bersangkutan dan bagi guru yang lain.

4. Bagi peneliti lain, perlu diadakan penelitian lebih lanjut tentang penelitian ini dengan variabel yang berbeda yang turut memberikan pengaruh terhadap komitmen organisasi guru, mengingat adanya keterbatasan dalam pelaksanaan penelitian dan hasil yang diperoleh belum maksimal.

\section{F. DAFTAR PUSTAKA}

Ambarita, B. 2010. Analisis Alur Utama Hubungan Variabel Penentu Kinerja Dosen ( Pengaruh Kepemimpinan, Manajemen Personalia, Budaya Organisasi, dan komitmen Organisasi terhadap kinerja Dosen di Universitas Negeri Medan). Disertasi. Program Pasca Sarjana Universitas Negeri Medan

Asiah. 2016. Pengaruh Komunikasi Persuasif Kepala Sekolah,Aktualisasi diri guru, dan Kepuasan Kerja terhadap Komitmen Organisasi guru SMP Muhammadiyah Kota Medan. Tesis, medan: Program Pasca Sarjana Universitas Negeri Medan. 
Colquitt, J.A., Lepine, J.A., dan Wesson, M.J., 2009. Organizational Behavior: Improving Performance and Commitment in the Workplace. New York: the Mc. Graw-Hill Companies.

Dasmiati. 2013. Pengaruh Persepsi Guru tentang Kecedasan Emosional Kepala Sekolah, Iklim Kerja, dan Motivasi Berprestasi terhadap komitmen Guru Sekolah Luar Biasadi Kota Medan. Tesis, medan: Program Pasca Sarjana Universitas Negeri Medan.

Hutabarat, W., 2014. Pengaruh Budaya Organisasi,Struktur Organisasi, Motivasi Kerja dan Kepuasan Kerja terhadap Kinerja GuruSMA Negeri Kota Medan. Disertasi, medan: Program Pasca Sarjana Universitas Negeri Medan.

Kreitner, R. dan Kinicki, A., 2007. Organizational Behavior. New York: McGraw-Hill.

Luthans, F., 1992. Organizational Behavior. New York: McGraw-Hill.

Mathis, R.I. dan Jackson J.H. 2000. Human Resources Management. New Jersey: Prentice Hall.

Rivai, V., 2009. Manajemen Sumber Daya Manusia untuk Perusahaan dari Teori ke Praktik. Jakarta: Raja Grafindo Persada.

Robbins, P.S., 1991. Organizational Behavior: Concept, Controvercies, Aplications. New Jersey: Hall International, Inc.

Robbins, P. S., dan Judge, T.A., 2009. Organizational Behavior. New Jersey: Pearson Education, Inc.

Siburian, P., 2009. Pengaruh Komunikasi Interpersonal dan Motivasi Berprestasi terhadap Kepuasan kerja. Studi Kausal pada SMA Parulian 2 Medan. Medan: Program Pasca Sarjana Universitasnegeri Medan.

Siburian, S.M., 2015. Pengaruh Komunikasi Interpersonal, dan Motivasi Berprestasi terhadap Kinerja Guru Sekolah Dasar Kecamatan Tanjung Morawa. Tesis, Medan: Program Pasca Sarjana Universitas Negeri Medan.

Siregar, A.N., 2014. Pengaruh Budaya Sekolah, Kecerdasan Emosional, dan Pengelolaan Stres Kerja Terhadap Komitmen Organisasi Guru Sekolah Menengah Atas Negeri Kabupaten Padang Lawas. Tesis. Medan: Program Pascasarjana, Universitas Negeri Medan.

Sopiah. 2008. Perilaku Organisasi. Yogyakarta: CV. Andi Offset.

Sudjana. 1996. Metode Statistika. Bandung: Tarsito

Undang-undang No.14 Tahun 2005. Tentang Guru dan Dosen. Jakarta: Sinar Grafika.

Undang-undang No. 20 tahun 2003. Tentang Sistem Pendidikan Nasional.

Usman, Husaini. 2006. Manajemen Teori Praktik dan Riset Pendidikan. Edisi Pertama. Jakarta: Bumi Aksara. 